\title{
Institutionalization Strategy Enhancing Firm Resources: Isomorphism from Firms and Its Strategic Implications
}

\author{
Seung Hoon Jang ${ }^{1}$, Byung Ku Lee ${ }^{2} \&$ Samuel A. Nelson ${ }^{3}$ \\ ${ }^{1}$ College of Business, Bloomsburg University of Pennsylvania, Bloomsburg, USA \\ ${ }^{2}$ Department of Management and Leadership, College of Business and Public Management, University of La Verne, \\ La Verne, USA \\ ${ }^{3}$ Center for Entrepreneurship, University of Nebraska-Lincoln, Lincoln, USA \\ Correspondence: Dr. Seung Hoon Jang, College of Business, Bloomsburg University of Pennsylvania, 337 Sutliff \\ Hall, East 2nd Street, Bloomsburg, PA, 17815, USA. E-mail: sjang@bloomu.edu
}

Received: May 23, 2014

Accepted: June 16, 2014

Online Published: August 10, 2014

doi:10.5430/jms.v5n3p1

URL: http://dx.doi.org/10.5430/jms.v5n3p1

\begin{abstract}
The aim of this study is to provide a theoretical framework concerning how firms exert isomorphic pressures to survive and thrive in the existing market. In addition to the institutional strategies (Lawrence, 1999), the authors clarify the relationship among isomorphic pressures from firms, the value of firm resources, and sustainable competitive advantage. For this purpose, this paper reviews institutional isomorphism and relevant theories like resource based view, transaction cost theory, and resource dependency theory. It then provides propositions based on theoretical reviews and inferences. Firms are expected to strengthen their resources by exerting various isomorphic pressures: coercive, mimetic, and normative. Therefore, they are more likely to beat competitors even in the existing markets. The implications are discussed at the end of the paper. First of all, this study provides an extension to the horizon of institutionalization strategies by providing an additional viewpoint. In addition, it enlightens the importance of firm strategies based on corporal isomorphic pressures. Practitioners are recommended to consider their firms' ability to conform other stakeholders as a significant strategic asset.
\end{abstract}

Keywords: institutionalization, resource, competitive advantage, strategy

\section{Introduction}

For many years, studies have suggested and demonstrated that environmental factors offer complementary explanations concerning firms and their behavior. Lawrence and Lorsch (1967) suggested that environmental uncertainty is a major factor in the organization field. Hannan and Freeman (1977) investigated the density of population as a main indicator of organizational survival. Pfeffer and Salancik (1978) proposed that the external dependence of firms to achieve valuable resources is important for their survival. Organizational innovation has also shown to rely on outside knowledge (Chatterji \& Fabrizio, 2013; Chesbrough, 2003; Lee \& Olson, 2010). Overall, environmental factors have been the integral parts of strategy and organization. Conventionally, researchers in this field have been interested in how organizations respond to institutional forces. Several studies have explored how firms to adopt external institutions, including quality management practice (Kostova \& Roth, 2002), governance structure (Lee \& Pennings, 2002), and organizational routine (Massini, Lewin, \& Greve, 2005). Furthermore, Milstein, Hart, and York (2002) recognized that a coercive pressure can lead to heterogeneous results due to environmental variation. As can be seen in the existing literature, firms have been considered as the objects of environmental impacts.

After DiMaggio and Powell (1983) recognized that firms can be the sources of isomorphic pressures, several researchers have explored this issue thoroughly. The growing significance of corporate organizations in modern society implies that firms can be the origins of institutional influences. Firms may unintentionally mislead stockholders by providing wrong information (Largevoort, 1997). Wade, O'Reilly, and Chandratat (1990) suggested that CEOs can exert social influences to achieve favorable conditions. The literature opens possibilities that firms can be the sources of important social influences, including institutional isomorphism (DiMaggio \& Powell, 1983). Following this notion, Lawrence (1999) proposed institutional strategies based on the isomorphic pressures from the 
firms. In order to create favorable competitive environment, firms affect the rules of members (membership strategy) or enforce formal or informal standards (standardization strategy).

Although Lawrence (1999) explained that both types of institutional strategies may result in favorable competitive environment, the focus of his propositions lied on how firms exert institutional pressures rather than how these pressures lead to sustainable competitive advantage. Furthermore, the author mainly paid attention to the establishment of new rules rather than the influence on firm resources in the existing markets. Given the continued importance of enduring success in business for the organization and strategy literature (Barney, 1991), there is need to explore this overlooked aspect of institutionalization strategies.

From this perspective, this study makes advances in complementing institutional strategies of Lawrence (1999). The aim of this study is to clarify the relationship among institutional strategies, firm resources and sustainable competitive advantage in order to gain in-depth knowledge in a feature of business competition in these days. To achieve this objective, the literature in institutionalization and related managerial theories are examined. Based on the review, a theoretical framework and propositions explaining how isomorphic pressures from firms can be strategically used to enhance their resources and competitive advantage. In the final section, the implications of this study and future research directions are discussed.

\section{Isomorphic Pressures from Firms}

Environmental influences on firms have long been a major topic in organization and management field. Since Lawrence and Lorsch (1967) focused on external factors interacting with organizations, much more efforts have been made to investigate contextual influences as well as internal dynamics (e.g. Lee \& Miller, 1996). The literature on population ecology also has provided that organizations are less likely to survive when there are more competitors in the field (Hannan \& Freeman, 1977). Scholars in this research stream have unveiled the characteristics of institutional influences. What these studies imply is that conventional scholars have mainly focused on how environmental stimuli impact organizations. In other words, firms have been considered to simply be passive responders rather than active initiators to their environment.

DiMaggio and Powell (1983) provided three major pressures explaining the homogeneity of firms. Firstly, coercive isomorphic pressure is originated from government legislative or administrative activities (DiMaggio \& Powell, 1983). Other external entities, including civil organizations, indirectly exert such influences by interacting regulators. As a result, business organizations become similar since they should comply with the same pressure from these agencies. Legal pressures, certain types of coercive influences, have been expected to explain whether non-profit organizations report their financial information (Verbruggen, Christiaens, \& Milis, 2011).

Secondly, mimetic isomorphic pressure can be described as benchmarking of more successful firms under uncertain situations (DiMaggio \& Powell, 1983; Lawrence, 1999). This process explains the homogeneity among organizations since they tend to imitate the industry leader. For instance, firms in the electronics industry tend to adopt new practices of initiators like GE, Samsung or Sony when they do not have their own policies or values regarding the issues. Mimetic factors like the number of market participants and successful units have shown to explain corporate decisions regarding the entrance to a new market (Haveman, 1993). Exporters in emerging countries are also recommended to benchmark the generic product strategy of a multinational enterprise (MNE) in a home-country (Brouthers, O'Donnell, \& Hadjimarcou, 2005). While premium strategy has been effective in Japan, economy strategy has been successful in U.S.

Finally, normative isomorphic pressure explains the similarity of firms based on the common professional experiences or memberships among firms or key people (DiMaggio \& Powell, 1983; Lawrence, 1999). For instance, consultants trained in the McKinsey tend to utilize and spread what they learned at the firm even though they currently work for different employers. Therefore, the practices or know-hows of McKinsey retirees are more likely to be implicit rules in the industry. "McKinsey ways" like presentation techniques have shown to be considered as certain types of guidelines (Rasiel, 1999).

Modern firms, however, are expected to emit social influences rather than passively respond to environmental stimuli. The literature on corporate social responsibility implies that various stakeholder groups depend on firms for a significant portion of their resources (McWilliams \& Siegel, 2001). When considering the studies maintaining that organizations can be controlled by outside entities based on the level of resource dependency (Pfeffer \& Salancik, 1978), it seems likely that modern firms providing a significant level of valuable resources can exert social influences on external organizations. For instance, firms are expected to have an influence on the decision-making processes of community organizations when they support charities. 
Paradoxically, these social pressures can strengthen the competitive superiority of the firms from internal capabilities perspective. Since Penrose (1959) initially recognized the significance of internal resources, firm resource has been considered as additional origin of competitive advantages and better performance. Wernerfelt (1984) suggested a resource-based view in which the heterogeneous market results are mainly due to organizational resources. The resource-based view was refined and developed by the study of Barney (1991) from the theoretical perspective. In the same article, certain types of resource characteristics were focused as the indicators of the routes toward sustainable competitive advantage. Therefore, corporate organizations are more likely to retain superior positions among fierce competitions when external influences enhance firm resources. Given the significant influences of external factors on firms and their strategy, the influence of firms' isomorphic pressures on competitive advantage is required to be investigated. For this purpose, the literature concerning institutionalization from firms and its strategic impacts on competitive advantage is reviewed in the next section.

\section{Isomorphic Pressures and Competitive Advantage}

\subsection{Coercive Isomorphism, Resource, and Competitive Advantage}

Firms are expected to emit coercive pressures toward the external environment. Lawrence (1999) also mentioned that firms exert isomorphic pressures deliberately to benefit from favorable competitive environment. One of major instruments which enable firms influence regulators or legislators is lobbying. Much interests have been given on the various issues of firm lobbies, including the schedule of emission tax (Damania \& Fredriksson, 2000) and the lobbying power of foreign firms in countries dependent on FDI (Cole \& Frederiksson, 2009). Eventually, firms can exert coercive isomorphism when agencies reflect what firms ask for in the form of new legislations, or administrative practices as seen on the figure 1 .

The coercive influences from firms are expected to enable firms to create favorable contexts. The establishment of a regulation or deregulation reflecting the opinions of a firm may bring about new changes which enhances its status as a market participant. For instance, new tariffs on foreign products may improve the competitive environment of local businesses. Steel and auto industries have shown to lobby publics as well as agencies to protect their markets (Baldwin, 1989).

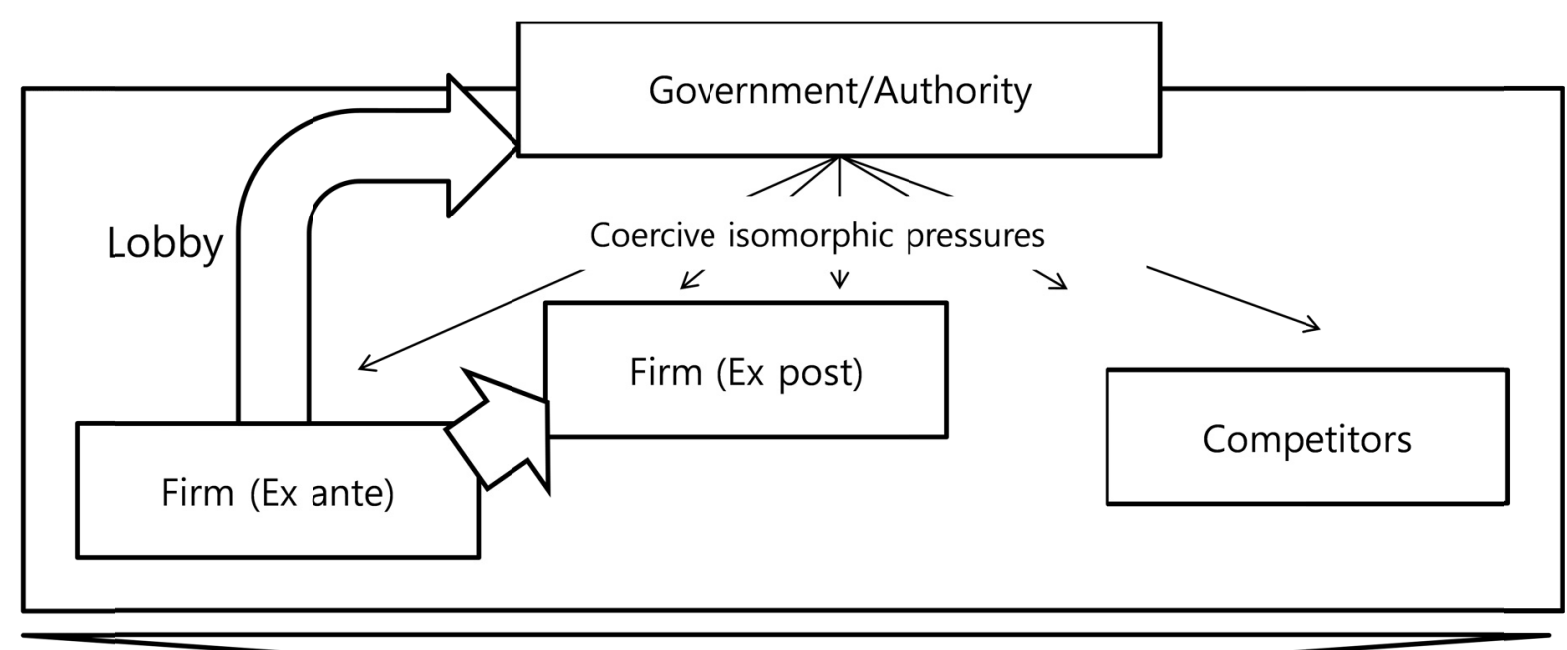

\section{Competitive advantage}

Figure 1. Coercive isomorphic pressures from a firm and sustainable competitive advantage

Superior resources have shown to be achieved by the firms when they exert coercive pressures. The earlier discussion on firm influences on emission tax (Damania \& Fredriksson, 2000) or countries dependent on FDI (Cole \& Frederiksson, 2009) provide meaningful implications regarding this issue. If firms succeed to persuade the government or legislators to regulate or pass laws as expected, it seems likely that valuable resource like funds or HR is more likely to be accumulated in the firm. For instance, corporate organizations are expected to spend less for the 
same number of employees due to the change of immigration laws. Therefore, these firms with valuable resources are more likely to win than the competition as Barney (1991) provided.

To summarize the above discussion, we offer the following proposition:

Proposition 1-a Firms exert coercive isomorphic pressures to retain more valuable resources. As a result, firms are expected to achieve sustainable competitive advantage.

Transaction cost Since Coase (1937) recognized that certain types of cost may occur due to market exchanges, scholars in this research stream have explored the transaction cost of organizations (Lo, Frias, \& Ghosh, 2011). Transaction cost theory has been used to explain multiple firm behaviors, including strategic alliance (Parkhe, 1993), bargaining power (Argyres \& Liebeskind, 1999), the survival of joint ventures (Pearce, 1997), and multinational strategy (Rugman \& Verbeke, 1992). Based on the literature, it is beyond doubt that transaction cost theory is one of major theoretical foundations of organization and management field.

The primary logic underpinning transaction cost theory is that firms may lose out when other organizations behave opportunistically (Williamson, 1973). Firms cannot monitor all of such behaviors even when other participants distort important information. For instance, a venture capitalist may not find out that high tech ventures have exaggerated the value of their new products to achieve more funds because of the lack of time to acquire this information. Therefore, firms suffer from their improper managerial decision, resulting in the loss of their value.

Coercive isomorphic pressures from regulators or legislators (DiMaggio \& Powell, 1983) enable firms to restrain opportunistic behaviors of external organizations. Particularly, certain types of opportunistic behavior have shown to threaten firm competitive advantage (Barney \& Hansen, 1994). Gundlach, Achrol, and Mentzer (1995) criticized that exchange participants may lose out when a party behaves opportunistically. Tripsas, Schrader, and Sobrero (1995) provided that the government needs to oppress opportunistic behaviors for the success of collaborative R\&D. For example, if a firm succeeds to persuade government officials to enhance and apply a copyright act, the production of clones will be prohibited or restrained.

The lowered risk of opportunistic behavior enables firms to retain competitive advantage. Following the notion of Barney (1991), and Choi and Beamish (2013), the scarcity of valuable resources is expected to lead to the sustainable competitive advantage of the firm. Scholars like Chen, Cheng, and Hwang (2005) exhibited that the intellectual capital of a firm plays a critical role in explaining its market value and financial performance. Enhanced legislations on firm resources like intellectual capital enable firms to retain the paucity of their resources, leading to successful competition.

Proposition 1-b Firms exert coercive isomorphic pressures to make their resources hard to be imitated by others. As a result, firms are expected to achieve sustainable competitive advantage.

Resource dependency theory Resource dependency theory has been used to explain inter-organizational dynamics. Pfeffer and Salancik (1978) initially suggested that the influence of outside entities on an organization increases when they provide core resources. Resource dependence has shown to be a major topic in the organizational and management field (Drees \& Heugens, 2013; Ulrich \& Barney, 1984). Several scholars in this area have examined diverse features of business management, including the role of the board (Hillman, Cannella, \& Paetzold, 2000). What these studies imply is that firms can achieve a superior position in the industry when they retain valuable resources.

Certain types of coercive isomorphic pressures are expected to strengthen the value of firm resources based on the influence on external entities. Laeven and Levine (2006) provided that the laws protecting small shareholders may diminish the influences of large shareholders on corporate behaviors. Banks may lobby to modify existing regulations to increase their influences based on their capital investment on other firms. If they succeed, it seems likely that an organization dependent on the banks is more likely to reflect their opinions on management.

Firms can retain competitive advantage by emitting these social influences. Other organizations tend to seek the best interests of a firm providing valuable critical resources (Pfeffer \& Salancik, 1978). For example, a bank is more likely to achieve valuable resources from businesses under its influences, leading to sustainable competitive advantage. Administrative or legislative changes can enhance the impacts of resource dependent relationships. Therefore, the firm is expected to compete against other organizations successfully as Barney (1991) proposed.

Proposition 1-c Firms exert coercive isomorphic pressures to strengthen their power on others based on their resource, resulting in increased value of the resources. As a result, firms are expected to achieve sustainable competitive advantage. 


\subsection{Mimetic Isomorphism, Resource, and Competitive Advantage}

As Lawrence (1999) mentioned, certain types of mimetic isomorphic pressures can be aroused from firms. Firms emit institutional influences through the diffusion of their best standards or practices (DiMaggio \& Powell, 1983). Other organizations are expected to adopt the external impact when they perceive that it is the optimal solution to the uncertain situation of an industry leader. Several famous cases, including IBM vs Apple (West, 2005), have supported this notion. IBM allowed other manufacturers produce clones, leading to the dominant status of its standard against Apple in the PC market.

Such influences enable firms to benefit strategic advantages since their existing resources can hardly be substituted (Figure 2). The expansion of a standard restrained consumers from searching alternatives. The expectation on present and future network sizes have been expected to enhance consumers' choices of certain types of technology (Park, 2004). Despite the fact that the margin of a single firm may decrease, firms have shown to benefit from the diffusion of their technical standard because of the increase and dominance of their market share (West, 2005). As more suppliers or distributors follow the firm's standard, new market participants are less likely to adopt another one. In addition, the newly formed stakeholders like video contents providers will act as additional social pressures since they tend not to lose their sunk cost concerning the established industry standard.

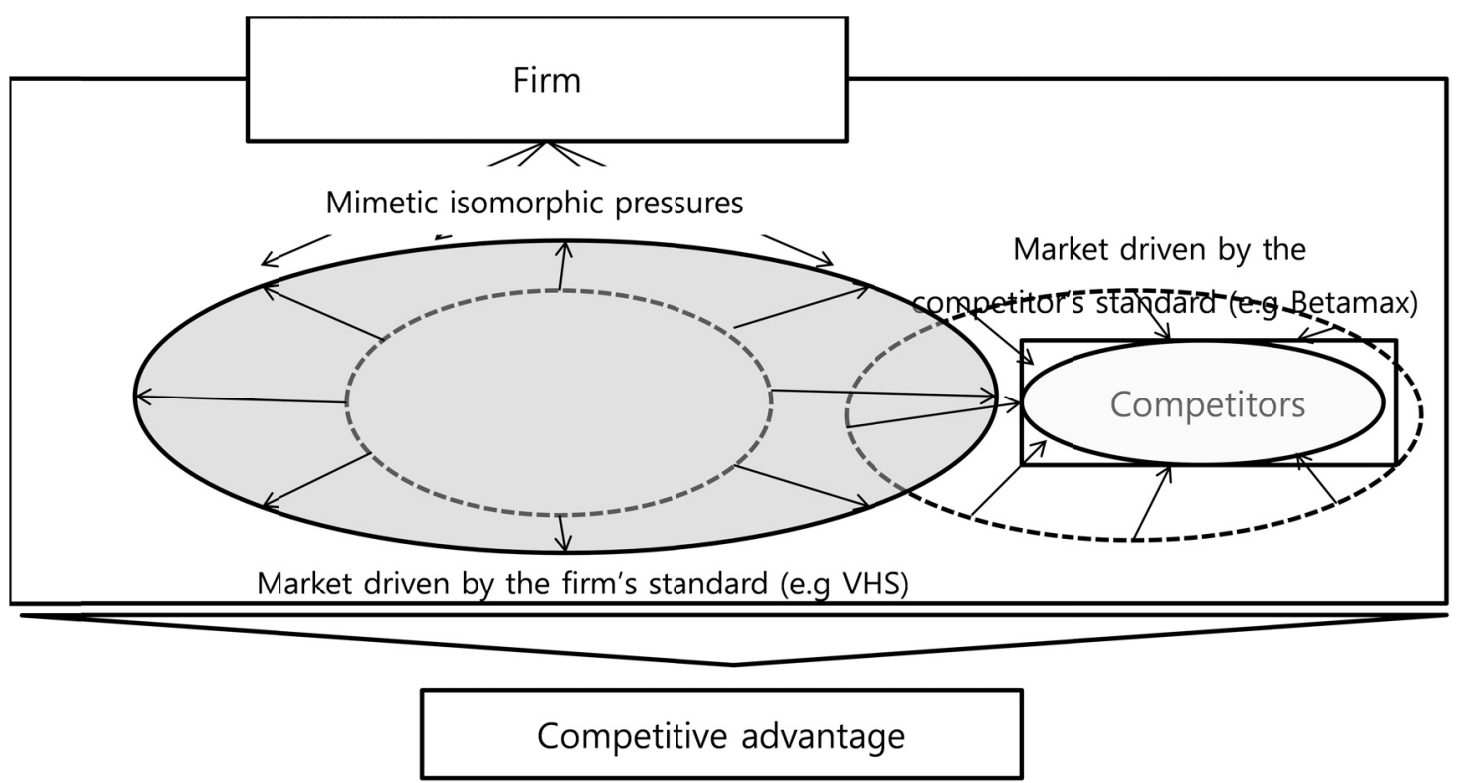

Figure 2. Mimetic isomorphic pressures from a firm and sustainable competitive advantage

Although more businesses may participate in the competition under the same industry standard, the original sources of the mimetic pressures are expected to retain dominant and superior position due to the enhanced value of their resources. First of all, it seems likely that initiators of new products or technologies retain core patents or copyrights. Even though competitors succeed to enter the market, they owe costs concerning the patents. As a result, these original firms benefit from financial perspectives, resulting in sustainable competitive advantage. In addition, firms already exploring uncertainty are expected to retain the sufficient technological and managerial basis. Therefore, the R\&D capacity of pioneering firms enables them to continue innovating their product or service, resulting in their competitive advantage.

In sum, firms are expected to retain competitive advantage by utilizing their mimetic influences. The successful diffusion of a protocol enhances the value of their resources. Once an industry standard dominates, consumers are less likely to substitute for alternative ways. Therefore, these firms are more likely to beat other competitors

To summarize, we propose:

Proposition 2 Firms make their resources valuable and hard to be substituted by exerting mimetic isomorphic pressures. As a result, firms are expected to achieve sustainable competitive advantage 


\subsection{Normative Isomorphism, Resource, and Competitive Advantage}

Normative isomorphic pressures can be originated from firms. Particularly, executives with the similar background (e.g. ex-employer) are expected to be the core of social influences from the firms from at least two perspectives as DiMaggio and Powell (1983) mentioned. First, employees in the same employer are more likely to experience managerial or technical practices from the explicit and implicit training in the firm. Given the significance of workplace learning in the improvement of employees' capabilities (Huselid, 1995), it seems likely that individual retirees from the similar training programs retain comparable capabilities. Therefore, the practices will be diffused when these employees move to other corporate organizations, leading to the homogeneity among firms.

In addition, firms can emit normative isomorphic influences by distributing information via their networks as Lawrence (1999) described. Social network has long been the major source of knowledge transfer and sharing. Granovetter $(1973,1983)$ provided that weak ties are more likely to provide useful information. Krackhardt (1992) provided that strong ties enable individuals to access valuable information easily. Lai and Wong (2002) suggested that information is more likely to spread at the strong rather than weak ties. Therefore, corporate organizations within the social network tend to be similar since they are more likely to decide and behave based on the common information.

These social influences enable firms to improve the value of their resources. Scholars like Hatch and Dyer (2004) recognized that individual employees learn firm specific technology through formal or informal training opportunities. The technology of a firm is more likely to be a standard when its retirees have been spread into other businesses (e.g. venders) in the industry. It is because decision makers of such businesses may decide to adopt the familiar technology when other conditions are similar. For instance, executives trained at GE are expected to follow its managerial and technical standards even when they move to corporations. Consumers are less likely to use alternative products or service as the technology dominates the industry. Therefore, the firm is expected to benefit from increased value since it is not easily substituted (Barney, 1991)

In sum, the competitive advantage can originate from normative influences from firms. These isomorphic pressures may enhance internal capacities of firms ahead of their competitors. As a result, the firms are expected to benefit from common best practices or information diffused through the social network. Therefore, they are more likely to compete successfully.

To summarize, we propose:

Proposition 3 Firms make their resources hard to be substituted by exerting normative isomorphic pressures. As a result, firms are expected to achieve sustainable competitive advantage.

\section{Discussion and Conclusion}

In this study, authors explored the new-institutionalization from the new perspective. Firms are viewed as creators of their surrounding environment rather than passive adopters of external standards. Coercive, mimetic, and normative isomorphic pressures from firms create favorable environments. Therefore, these firms are more likely to compete successfully in the market.

This study provides several meaningful implications. First of all, the authors provided an extension to the horizon of institutionalization strategy by providing an additional viewpoint. In contrast to most existing studies which have focused on the creation of new environment, it is posited here that firms can improve their internal resources and ultimately enhance sustainable competitive advantage. That is to say, this study enlightens the importance of firm strategies based on their social influences. Certain types of isomorphic pressures account for the competitive advantage of firms and researchers interested in this topic can broaden the realm of strategic management and competitive advantage.

Practitioners are recommended to consider their firms' ability to influence their internal capacities as well as external environment as a significant strategic asset. The decision regarding the amount of effort put forth on the exertion of their coercive, mimetic, and normative influences is an integral part of the strategic management process. Given the importance of firm resources for the strategies, managers should reflect these social influences and their results in their strategic plans. This type of reciprocal relationship allows a firm to shape their environment, instead of simply responding to it. Subsequently, a firm can leverage types of influential relationship within the industry to achieve a competitive advantage.

Future researchers should pay attention to the isomorphic pressures exerted from firms and the changes these forces have on the internal resources which they utilize. The recommended research directions can serve to guide interested 
organization and management scholars in future research. First of all, the influences of inter-relationships among firms, agencies, and other stakeholders on the direction and degree of coercive institutional influences need to be investigated. Given the social influence from firms, it seems likely that each organization is capable of exerting their own institutional power towards other firms within their environment. In addition, the paradox between the effects of mimetic and normative isomorphism from firms and resource scarcity should also be examined. Competitors can imitate the unique capabilities of others when they unveil and spread their practices to exert institutional pressures. The guidance on these issues is expected to enrich our understanding of these types of institutional influences and their strategic meaning.

\section{References}

Argyres, N. S., \& Liebeskind, J. P. (1999). Contractual commitments, bargaining power, and governance inseparability: Incorporating history into transaction cost theory. Academy of Management Review, 24, 49-63.

Astley, W. G., \& Fombrun, C. J. (1983). Collective strategy: Social ecology of organizational environments. Academy of Management Review, 8, 576-587.

Baldwin, R. E. (1989). The political economy of trade policy. Journal of Economic Perspectives, 3, 119-135. http://dx.doi.org/10.1257/jep.3.4.119

Bandura, A. (1977). Social learning theory. New York, NY: General Learning Press.

Barney, J. B. (1991). Firm resources and sustained competitive advantage. Journal of Management, 17, 99-120. http://dx.doi.org/10.1177/014920639101700108

Barney, J. B., \& Hansen, M. H. (1994). Trustworthiness as a source of competitive advantage. Strategic Management Journal, 15, 175-190. http://dx.doi.org/10.1002/smj.4250150912

Brouthers, L. E., O'Donnell, E., \& Hadjimarcou, J. (2005). Generic product strategies for emerging market exports into triad nation markets: A mimetic isomorphic approach. Journal of Management Studies, 42, 225-245. http://dx.doi.org/10.1111/j.1467-6486.2005.00495.x

Chatterji, A. K., \& Fabrizio, K. R. (2013). Using users: When does external knowledge enhance corporate product innovation? Strategic Management Journal, Online early view version. http://dx.doi.org/10.1002/smj.2168

Chen, M-. C., Cheng, S. J., \& Hwang, Y. (2005). An empirical investigation of the relationship between intellectual capital and firms' market value and financial performance. Journal of Intellectual Capital, 6, 159-176. http://dx.doi.org/10.1108/14691930510592771

Chesbrough, H. W. (2003). Open innovation: The new imperative for creating and profiting from technology. Boston, MA: Harvard Business School Press.

Choi, C., \& Beamish, P. W. (2013). Resource complementarity and international joint venture performance in Korea. Asia Pacific Journal of Management, 30, 561-576. http://dx.doi.org/10.1007/s10490-011-9258-4

Coase, R. H. (1937). The nature of the firm. Economica, 4, 386-405. http://dx.doi.org/10.1111/j.1468-0335.1937.tb00002.x

Cole, M. A., \& Fredriksson, P. G. (2009). Institutionalized pollution havens. Ecological Economics, 68, 1239-1256. http://dx.doi.org/10.1016/j.ecolecon.2008.08.011

Daft, R. (1983). Organizational theory and design. New York: West Publishing.

Damania, R., \& Fredriksson, P. G. (2000). On the formation of industry lobby groups. Journal of Economic Behavior \& Organization, 41, 315-335. http://dx.doi.org/10.1016/S0167-2681(99)00079-7

DiMaggio, P. J., \& Powell, W. W. (1983). The iron cage revisited: Institutional isomorphism and collective rationality in organizational fields. American Sociological Review, 48, 147-160. http://dx.doi.org/10.2307/2095101

Drees, J., \& Heugens, P. (2013). Synthesizing and extending resource dependency theory: A meta-analysis. Journal of Management, 39, 1666-1698. http://dx.doi.org/10.1177/0149206312471391

Granovetter, M. S. (1973). The strength of weak ties. American Journal of Sociology, 78, 1360-1380. http://dx.doi.org/10.1086/225469

Granovetter, M. S. (1983). The strength of weak ties: A network theory revisited. Sociology Theory, 1, 201-233. http://dx.doi.org/10.2307/202051

Greening, D. W., \& Gray, B. (1994). Testing a model of organizational response to social and political issues. 
Academy of Management Journal, 37, 467-498. http://dx.doi.org/10.2307/256697

Gundlach, G. T., Achrol, R. S., \& Mentzer, J. T. (1995). The structure of commitment in exchange. Journal of Marketing, 59, 78-92. http://dx.doi.org/10.2307/1252016

Hannan, M. T., \& Freeman, J. (1977). The population ecology of organizations. American Journal of Sociology, 82, 929-964. http://dx.doi.org/10.1086/226424

Hatch, N. W., \& Dyer, J. H. (2004). Human capital and learning as a source of sustainable competitive advantage. Strategic Management Journal, 25, 1155-1178. http://dx.doi.org/10.1002/smj.421

Haveman, H. A. (1993). Follow the leader: Mimetic isomorphism and entry into new markets. Administrative Science Quarterly, 38, 628-652. http://dx.doi.org/10.2307/2393338

Hillman, A. J., Cannella, A. A., \& Paetzold, R. L. (2000). The resource dependence role of corporate directors: Strategic adaptation of board composition in response to environmental change. Journal of Management Studies, 37, 235-255. http://dx.doi.org/10.1111/1467-6486.00179

Hoskisson, R. E., Hitt, M. A., Wan, W. P., \& Yiu, D. (1999). Theory and research in strategic management: Swings of a pendulum. Journal of Management, 25, 417-456. http://dx.doi.org/10.1177/014920639902500307

Huselid, M. A. (1995). The impact of human resource management practices on turnover, productivity, and corporate financial performance. Academy of Management Journal, 38, 635-672. http://dx.doi.org/10.2307/256741

Kaplan, S. (2008). Cognition, capabilities, and incentives: Assessing firm response to the fiber-optic revolution. Academy of Management Journal, 51, 672-695.

Kennedy, M. T., \& Fiss, P. C. (2009). Institutionalization, framing, and diffusion: The logic of TQM adoption and implementation decisions among U.S. Hospitals. Academy of Management Journal, 52, 897-918. http://dx.doi.org/10.5465/AMJ.2009.44633062

Kostova, T., \& Roth, K. (2002). Adoption of an organizational practice by subsidiaries of multinational corporations: Institutional and relational effects. Academy of Management Journal, 45, 215-233. http://dx.doi.org/10.2307/3069293

Krackhardt, D. (1992). The strength of strong ties: The importance of philos in organizations. In N. Nohria \& R. Eccles (Eds.), Neworks and Organizations: Structure, Form and Action (pp.216-239). Boston, MA: Harvard Business School Press.

Laeven, L., \& Levine, R. (2006). Corporate governance, regulation, and bank risk taking. Brown University Working Paper. Retrieved from http://www.ecb.int/events/pdf/conferences/ecbcfs_conf9/bank_stability_4_14.pdf

Lai, G., \& Wong, O. (2002). The tie effect on information dissemination: The spread of a commercial rumor in Hong Kong. Social Networks, 24, 49-75. http://dx.doi.org/10.1016/S0378-8733(01)00050-8

Largevoort, D. C. (1997). Organized illusions: A behavioral theory of why corporations mislead stock market investors (and cause other social harms). University of Pennsylvania Law Review, 146, 101-172. http://dx.doi.org/10.2307/3312706

Lawrence, P. R., \& Lorsch, J. W. (1967). Organization and environment: Managing differentiation and integration. Boston, MA: Division of Research, Graduate School of Business Administration, Harvard University.

Lawrence, T. (1999). Institutional strategy. Journal of Management, 25, 161-188. http://dx.doi.org/10.1016/S0149-2063(99)80008-7

Lee, J., \& Miller, D. (1996). Strategy, environment and performance in two technological contexts: Contingency theory in Korea. Organizational Studies, 17, 729-750. http://dx.doi.org/10.1177/017084069601700502

Lee, K., \& Pennings, J. M. (2002). Mimicry and the market: Adoption of a new organizational form. Academy of Management Journal, 45, 144-162. http://dx.doi.org/10.2307/3069289

Lee, S. M., \& Olson, D. L. (2010). Convergenomics: Strategic innovation in the convergence era. Burlington, VT: Gower Publishing.

Li, J., Lam, K., Sun, J., \& Liu, S. (2008). Strategic human resource management, institutionalization, and employment modes: An empirical study in China. Strategic Management Journal, 29, 337-342. http://dx.doi.org/10.1002/smj.655

Lo, D., Frias, K. M., \& Ghosh, M. (2011). Price formats for branded components in industrial markets: An integration of transaction cost economics and the resource-based view. Organization Science, Published online 
before print August 10, 2011. http://dx.doi.org/10.1287/orsc.1110.0689

Massini, S., Lewin, A. Y., \& Greve, H. R. (2005). Innovators and imitators: Organizational reference groups and adoption of organizational routine. Research Policy, 34, 1550-1569. http://dx.doi.org/10.1016/j.respol.2005.07.004

McWilliams, A., \& Siegel, D. (2001). Corporate social responsibility: A theory of the firm perspective. Academy of Management Review, 26, 117-127.

Milstein, M. B., Hart, S. L., \& York, A. S. (2002). Coercion breeds variation: The differential impact of isomorphic pressures on environmental strategies. In A. J. Hoffman \& M. J. Ventresca (Eds.), Organizations, policy, and the natural environment: Institutional and strategic perspectives (pp. xiii-xvii). Stanford, CA: Stanford University Press.

Oliver, C. (1997). Sustainable competitive advantage: Combining institutional and resource-based views. Strategic Management Journal, $18, \quad 697-713$. http://dx.doi.org/10.1002/(SICI)1097-0266(199710)18:9<697::AID-SMJ909>3.0.CO;2-C

Park, S. (2004). Quantitative analysis of network externalities in competing technologies: The VCR case. Review of Economics and Statistics, 86, 937-945. http://dx.doi.org/10.1162/0034653043125275

Parkhe, A. (1993). Strategic alliances structuring: A game theoretic and transaction cost examination of interfirm cooperation. Academy of Management Journal, 36, 794-829. http://dx.doi.org/10.2307/256759

Pearce, R. J. (1997). Toward understanding joint venture performance and survival: A bargaining and influence approach to transaction cost theory. Academy of Management Review, 22, 203-225.

Penrose, E. T. (1959). The theory of the growth of the firm. New York, NY: John Wiley.

Peteraf, M. A. (1993). The cornerstones of competitive advantage: A resource-based view. Strategic Management Journal, 14, 179-191. http://dx.doi.org/10.1002/smj.4250140303

Pfeffer, J., \& Salancik, G. R. (1978). The external control of organizations: A resource dependence perspectives. New York, NY: Harper \& Row.

Porter, M. (1979). How competitive forces shape strategy. Harvard Business Review, 57, 137-146.

Rasiel, E. M. (1999). The McKinsey way: Using the techniques of the World's strategic consultants to help you and your business. New York, N: McGraw-Hill.

Rugman, A. M., \& Verbeke, A. (1992). A note on the transactional solution and the transaction cost theory of multinational strategic management. Journal of International Business Studies, 23, 761-771. http://dx.doi.org/10.1057/palgrave.jibs.8490287

Sherer, P. D., \& Lee, K. (2002). Institutional change in large law firms: A resource dependency and institutional perspective. Academy of Management Journal, 45, 102-119. http://dx.doi.org/10.2307/3069287

Suarez, F. F., \& Utterback, J. M. (1995). Dominant designs and the survival of firms. Strategic Management Journal, 16, 415-430. http://dx.doi.org/10.1002/smj.4250160602

Tripsas, M., Schrader, S., \& Sobrero, M. (1995). Discouraging opportunistic behavior in collaborative R\&D: A new role for government. Research Policy, 24, 367-389. http://dx.doi.org/10.1016/0048-7333(93)00771-K

Ulrich, D., \& Barney, J. B. (1984). Perspectives in organizations: Resource dependence, efficiency, and population. Academy of Management Review, 9, 471-481.

Verbruggen, S., Christiaens, J., \& Milis, K. (2011). Can resource dependence and coercive isomorphism explain nonprofit organizations' compliance with reporting standards? Nonprofit and Voluntary Sector Quarterly, 40, 5-32. http://dx.doi.org/10.1177/0899764009355061

Wade, J., O'Reilly, C. A., III., \& Chandratat, I. (1990). Golden parachutes: CEOs and the exercise of social influence. Administrative Science Quarterly, 35, 587-603. http://dx.doi.org/10.2307/2393510

Wernerfelt, B. (1984). A resource-based view of the firm. Strategic Management Journal, 5, 171-180. http://dx.doi.org/10.1002/smj.4250050207

West, J. (2005). The fall of a Silicon Valley icon: Was Apple really Betamax redux? In R. Bettis (Ed.), Strategy in transition (pp. 274-301). New York, NY: Wiley.

Williamson, O. E. (1973). Markets and hierarchies: Some elementary considerations. American Economic Review, 63, 316-326. 